\title{
Social co-configuration in online language learning
}

\author{
Susan Y. H. Sun \\ Auckland University of Technology, New Zealand \\ Peter Goodyear \\ The University of Sydney, Australia
}

\begin{abstract}
University students involved in online courses play an active role in adapting the tasks they are set and the environment(s) in which they work. They also make adjustments to their working relationships with other people in an effort to improve their learning and/or fit study demands into wider life. The term co-configuration refers to the ways in which students customise what has been designed for them. Co-configuration is important but often invisible to the teachers and designers responsible for the courses. In this study, we focused on students' co-configuration where it has a strong social character. We drew on concepts from realist evaluation and the activity-centred analysis and design framework to examine students' social co-configuration. Twenty-six online language learning students were interviewed. Two main areas of social co-configuration emerged. Firstly, students coconfigured working methods and relationships, roles, and divisions of labour in order to tackle group tasks. Secondly, students purposefully wove learning activity into their wider social environment, creating a social fabric that further enhanced and enriched their learning opportunities. The findings provide insights into students' social co-configuration. We argue that this is important for educational designers who aim to understand the mechanisms that connect educational designs to learning outcomes.
\end{abstract}

Implications for practice or policy:

Help educational designers and teachers to:

- understand social co-configurative activity in online language learning

- know what goes on in the gap between teachers' designs and students' activities

- acknowledge that online language learning is socially situated

- acknowledge students' agency in reshaping what is designed for them

- $\quad$ shift design focus to student configuration, context, and mechanism.

Keywords: design for learning, online language learning, co-configuration, social coconfiguration, socially situated learning

\section{Introduction}

One of the main paradigms for carrying out research in educational technology is to measure associations between desirable educational outcomes and the use of a particular tool, resource, and/or teaching method. Put more generally, such studies aim to test whether a specific educational design or intervention is associated with significant benefit. Meta-analyses and systematic reviews are then used to aggregate findings (Baydas, Kucuk, Yilmaz, Aydemir, \& Goktas, 2015; Rientes \& Toetenel, 2016). However, such approaches tend to ignore, marginalise, or render opaque the processes that mediate between what is designed and the outcomes achieved. In systems modelling terms, they can be said to black-box these mediating processes by attending solely to inputs and outputs. Advocates of realist evaluation, in educational technology and elsewhere, are now arguing that what goes on inside the black box is key to understanding what works, for whom, in what circumstances, and why (Ellis \& Goodyear, 2019; Wong, Greenhalgh, \& Pawson, 2010; Wong, Greenhalgh, Westhorp, \& Pawson, 2012). This paper shows how students actively co-configure their learning environments and activities in online language learning. It opens the black box and sheds a clearer light on student agency.

In higher education, differences can occur between what academic staff intend their students to do and what the students actually do. University students' learning activities are mostly unsupervised, or only lightly supervised, especially in online courses. Without close guidance, students improvise sets of activities based on their interpretations of what is required, their prior study experiences and habits, and a range of other factors that constrain or enable moment-by-moment activity. Within the loosely coupled ecosystems of 
higher education, the tasks that teachers set, and the tools, working methods, and divisions of labour teachers recommend, can be seen as resources that students draw upon in shaping their own activities. These resources guide, but do not determine, students' activities and learning outcomes (Biggs \& Tang, 2007; Ellis \& Goodyear, 2010, 2019; Prosser \& Trigwell, 1999). Gaps between what teachers set in place and what students do are unavoidable. Gaps create risks, creating the danger that students may misunderstand their teachers' values or requirements, yet gaps are necessary. Without them, students may not develop the skills they need to manage their own learning and to participate with others in collaborative knowledge-building (Dohn, 2018). They may not be able to customise generic tasks to fit their own special interests and needs, and they may struggle to find ways of balancing competing demands on their time.

What happens in those gaps between what is designed and the outcomes that eventuate? What is it that students actually do when they are transforming designs into reality and away from the direct supervision of the teachers who design the courses? How do students interpret and modify the tasks set for them, and make decisions about what tools to use, where to work, and with whom? Investigations which try to answer these questions and provide insights into how educational designs work in real-life classrooms are therefore important. They can enrich educational designers' understandings of design and help them become more reflective and effective. This paper reports the outcomes from interviews with students who had taken fully online language learning courses. The focus is on students' co-configurations which have social dimensions; that is, the adaptations made by the students in order to work with others, including ways of building and broadening social connections/networks to enhance their language learning.

\section{Conceptual framework and approach to the problem}

In this section, we introduce a set of ideas from realist evaluation and the activity-centred analysis and design (ACAD) framework to frame our research problem: understanding how online language learning students actively co-configure their learning tasks and environment. Realist evaluation, like ACAD, is part of a paradigm shift in educational technology research and development, moving away from correlational studies of what works or what students like to tackle harder questions of what works for whom, in what circumstances, in what respects and how (Pawson, Greenhalgh, Gill, \& Walshe, 2005; Philip, Bang, \& Jackson, 2018; Wong et al., 2012). The focus is on explaining how the context, in which the educational intervention or design is applied, and the mechanisms, by which the intervention works, connect design to outcomes. Similarly, the ACAD framework (Carvalho \& Goodyear, 2014) focuses on learning activity which, they emphasise, is emergent as the result of mediation between the pre-design by the designers and the physical and social settings surrounding the learners.

\section{Realist evaluation}

Realist evaluation is an approach to understanding complex interventions, such as educational innovation projects. Grounded in the philosophy of social realism, it is attracting growing attention in educational fields, most notably in medical education (Lefroy et al., 2017; Wong et al., 2010; Wong et al., 2012). It is closely related to realist review: an approach to synthesising the research literature to elicit guidelines for policy and practice (Saul, Willis, Bitz, \& Best, 2013). Both realist evaluation and realist review try to understand educational interventions by reference to not only the outcomes, but most importantly the contexts and mechanisms. As Wong et al. (2012, pp. 92-93) explain:

An intervention itself does not directly change its participants; it is the participants' reaction to the opportunities provided by the programme that triggers the change ... the mechanisms by which educational interventions "work" are often multiple ... some mechanisms are obvious and correspond to those intended by the course designers ... some are less obvious and are unanticipated by the designers ... a mechanism is not inherent to the intervention, but is a function of the participants and the context ... mechanisms matter a great deal because they generate outcomes ... context matters a great deal because it changes (sometimes very dramatically) the processes by which an intervention produces an outcome.

This realist perspective gives a central place to what participants actually do, and how their actions are influenced by context. 


\section{The ACAD framework and student social co-configuration}

ACAD also focuses on what students actually do. It reflects larger, familiar, shifts in emphasis in educational design and practice: a move away from teachers-talking and students-listening, to students working actively on learning tasks which are designed and (where possible) supervised. Figure 1 captures the main elements of the ACAD framework as described by Carvalho and Goodyear (2014).

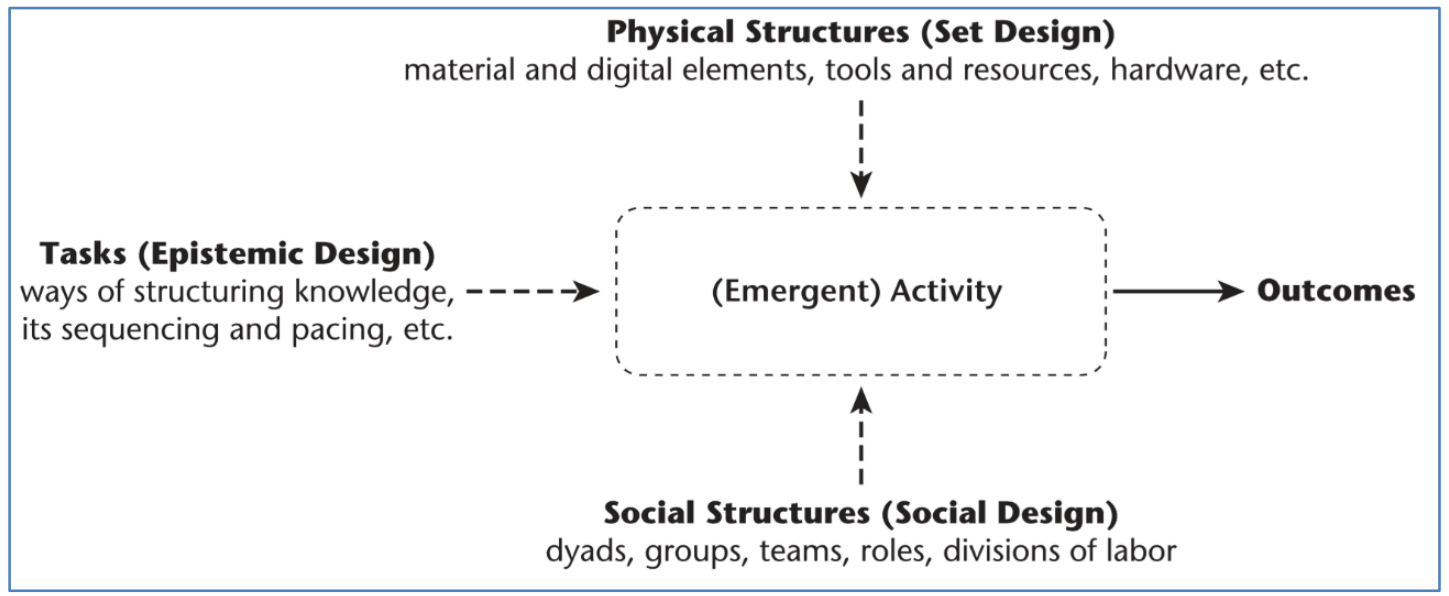

Figure 1. Tasks, tools, and people (Carvalho \& Goodyear, 2014, p. 135)

In ACAD, it is important to distinguish between (a) what can be designed (in advance) and (b) what emerges at learntime. The term activity is reserved for what students actually do. As such, it cannot be designed, though it can be designed for. What can be designed falls into three broad kinds of design components (the top, left, and bottom parts of Figure 1):

- Task (or epistemic) design - setting students worthwhile projects or challenges

- Set design - recommending tools, artefacts and other material or digital resources for tackling the suggested tasks; ways of finding and/or furnishing learning places, etc.

- Social design - recommending roles and ways of working with others, such as in pairs, teams, or as a member of a broader community of practice.

These elements become entangled at learntime, but they can be treated separately during design work. Of the three design components, task design is usually primary. In active learning situations, the task specification tells students what they ought to set out to do. Task designs also give students insights into the teacher-designer's understanding of the course, the curriculum requirements, intended learning outcomes, relevant domain knowledge, epistemology, etc. Set and social design components, on the other hand, serve the needs of the task (as designed) and the learning activity (as imagined). Social design might not be as visible or tangible as set design in a learning environment, but it is educationally important and needs to be separated out from set design because of the important role played by human agency and intentionality in the social realm.

In the ACAD model, learning activities (at the centre of Figure 1) are crucial in connecting what is designed to valued outcomes. Two kinds of emergent activities can be distinguished: activities intentionally directed at learning (accomplishing the task) and activities which dynamically (re)configure tasks and the physical and social situation, to better suit the students' needs and preferences. We use the term co-configuration to describe these acts of customisation. At a minimum, a single student will reconfigure what has been designed for them by a teacher-designer. On occasion, students collaboratively reconfigure what has been designed for them. In either case, the term co-configuration is appropriate as it captures the contributions of two or more people. Students, with or without close guidance by their teachers, co-configure their epistemic (task), physical and social environments on the fly. Students actively shape and tune the tasks they have been set into concrete learning activities, interpreting and interacting with the set design and social design as they do so. Examples include deciding on the best tools to use for a task, finding a quiet space to read in, searching for online resources, forming a discussion group, or dining out at a restaurant where they can practise speaking a new language. 
Designing with co-configuration in mind means designing in an open-ended way for the students' subsequent learning activity: explicitly acknowledging that they must complete the design. The idea of coconfiguration comes from design and innovation theory and recognises circumstances when the end users of a design (customers, clients, etc.) customise a designed product or service to better suit their own needs (Krippendorff, 2006; Markauskiate \& Goodyear, 2017). In education, this reflects the fact that learning activities and environments are typically emergent, evolving, co-designed and co-configured. This is not, as yet, widely acknowledged in the literature of educational design (Hokanson, Clinton, \& Tracey, 2015; Laurillard, Kennedy, Charlton, Wild, \& Dimakopoulos, 2018). Student co-configuration is subtly different from participatory design in which students have an explicit role in the upstream design process (DiSalvo, Yip, Bonsignore, \& DiSalvo, 2017). Co-configuration happens later, and the details may well be invisible to the teacher/designers.

Social co-configuration is concerned with ways of working on learning tasks with other people (e.g., agreeing divisions of labour, modes of collaboration, roles). They are important because learning is socially situated (Lave \& Wenger, 1991; O’Brien \& Battista, 2019). Socially situated learning activities are not, however, restricted to students' working with each other in classrooms (material or digital) to tackle the learning tasks set by their teachers. Social interaction, and learning activity more generally, "spills across the boundaries of formally designed sites for learning - like classrooms and lecture halls. It can occur anywhere" (Carvalho, Goodyear, \& de Laat, 2017, p. 1).

\section{Research focus}

A substantial body of research now exists on university students' general experiences of online learning (Murphy \& Stewart, 2017; Swan, 2001; Wallace, 2003). There has been surprisingly little research into how university students co-configure the material, and digital and/or social settings in which they learn (Bligh \& Crook, 2017; Crook \& Barrowcliff, 2001; Gallagher, Lamb, \& Bayne, 2017; Gourlay \& Oliver, 2017; Kahu, Stephens, Zepke, \& Leach, 2014; Kirkwood, 2000).

In this paper, we focus on co-configuration of the social: social environments, structures, and relationships. We share what students told us about how they worked with other people in the pursuit of their studies, how they built and strengthened relationships, how they adopted complementary roles, and so forth. Because the social, material, and digital elements become closely entangled in students' actual activity, some of our examples also mention the co-configuration of tasks and of physical (material and digital) learning environments, but all the examples in this paper have a strong social character to them. Indeed, we offer examples of how social co-configuration precedes, necessitates, and enables further physical and epistemic co-configuration. In short, we use ACAD as a way of orienting exploratory research to uncover examples of social co-configuration.

\section{Research context and data collection}

The study is set within the field of online language learning. The courses involved in the investigation were two fully online language (Chinese Mandarin) learning classes in a Bachelor of Arts program at a New Zealand university. They were delivered via the university's virtual learning environment (VLE) Blackboard. The courses were specially designed for beginners (Beginners I and II) who come from various courses of study or majors in the university and who are doing the language courses as electives or as part of a language minor. The majority of the students had no previous experience of learning online and they did not know each other at the start of the course. Yet, the courses were designed with an extremely strong focus on interactions and pair and group work. The goal was to help students develop a high level of communicative competence in the target language, oral communicative competence in particular. This can only be achieved through constant and consistent participation, interaction, and collaboration. The course design therefore focused on building a learning community (see Hod, Bielaczyc, \& Ben-Zvi, 2018; Kabat, 2014; Ouyang \& Scharber, 2017; Reimann, 2009; Xin, 2012, for discussion). Within the community, prominent design features included a buddy system, a virtual peer practice room which enabled 24/7 synchronous text, audio, and video communication, and a virtual studio. Students were required to pair or team up in the first week and work with their learning buddies on the weekly learning tasks. They needed to practise together, collaborate frequently, and submit pair or small group oral presentations as part of the assessment of the course. 
Twenty-six undergraduate students participated in the research. All participated in a 20-30-minute one-toone semi-structured interview. They were asked to talk about their lived experience of online language learning. By responding to general and open-ended questions such as "How did you go about studying the lessons?", "How did you go about organising and completing the group tasks?", the students provided rich accounts of their learning activities, many of which are examples of co-configuration. The interview questions covered most areas and aspects of students' required learning activities (e.g., self-learning tasks, pair/group tasks). The questions also drew students' attention to their social interactions (e.g., relationship building, working methods, roles and divisions of labour, resources drawn from social surroundings).

In addition to the interview data, two more data sources were employed. The interviewer (the first author of this paper who is also the teacher-designer of the courses) wrote an analytical memo for each interview (Corbin \& Strauss, 1990). The intention was to facilitate both initial and in-depth reflection, interpretation, and analysis of the interview data. Furthermore, several rounds of discussion with teaching colleagues were held in order to obtain their interpretations of and views on students' various learning activities. The interview data were triangulated with the analytical memos and peer discussions to improve the robustness, interpretability, and reliability of the analysis and findings.

\section{Analysis}

In analysing the data, we focused on and explored learning activities that had a strongly social character. We were interested in the social structures and relationships built and/or modified by the students. We identified all activities and examples in which students talked about how they interacted with their peers and with people in their wider social environments. An initial list of social co-configurations was compiled. The aim was to scope the range of examples of social co-configuration in online language learning. We see this as an important step towards longer-term research goals of identifying likely learning mechanisms implicated in social co-configuration activities in online language courses. Following guidelines from Creswell (2018), items in the initial list of social configurations were then hand-coded with a wide range labels, for example, organisation, socialising, responsibility, and getting outside help. This was followed by a windowing the data or axial coding process which aggregated the coded themes into a smaller number of categories. These categories went through another around of selective coding - uniting the themes around one or two central core categories, for example, co-configurations of tasks, co-configurations of social surroundings. As a result, the picture of student social co-configuration in online language learning emerged.

\section{Results and discussion}

Evidence of the socially situated nature of learning in these two fully online courses permeates the interview data. We present and discuss examples of social co-configuration in two parts, as shown in Figure 2.

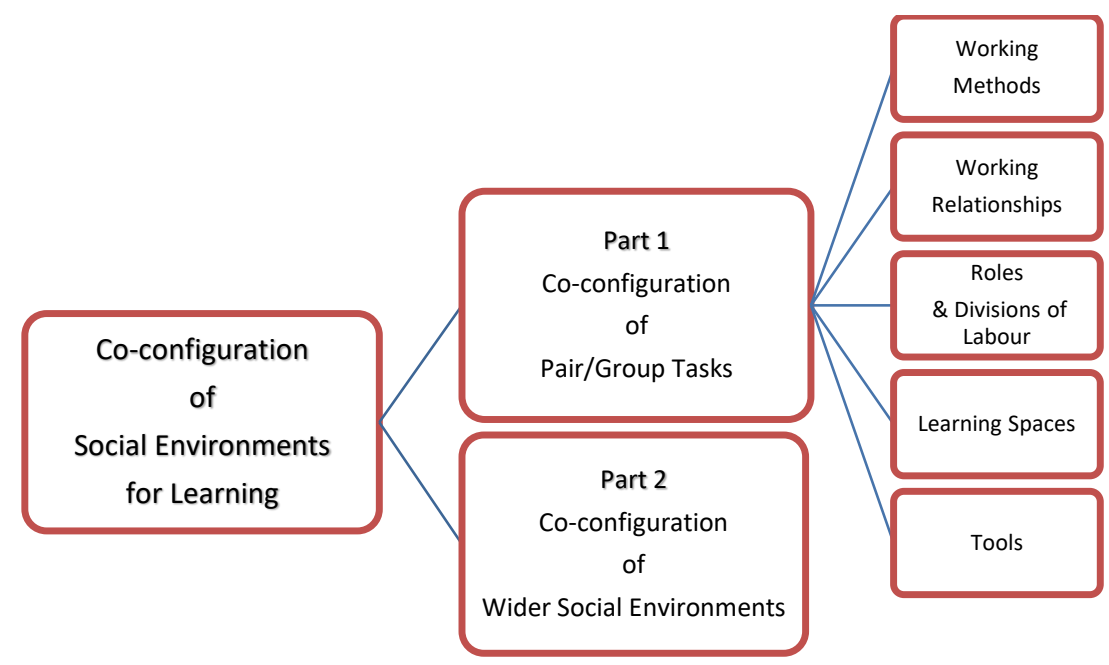

Figure 2. Scoping student social co-configuration in online language learning 
Part 1 was considered as a major area of investigation because pair or small group tasks were a central element in the design of the two courses and they required students to socialise and work together. The interview data indicates that was the case. Upon being given the pair/group tasks which the teachers had designed for them, students quickly got into action. They tried forming pairs or small groups and started co-configuring their working methods and relationships, roles, divisions of labour, learning spaces, tools, and so on. Part 2 was, however, an almost uncharted territory. The activities of individual students coconfiguring opportunities for learning with people in the wider social environments had been mostly invisible to the teachers. Although there have been reports that students and teachers sometimes experience a strong social presence in online education (Galley, Conole, \& Alevizou, 2011; Garrison, Anderson, \& Archer, 2000; Hauck \& Warnecke, 2012; Thomas, Reinders, \& Warschauer, 2012), very few details about personal social environments of learning, especially the ways students co-configure such environments, can be found in the online learning literature. The present study reveals how students purposefully and proactively involved other people in their activities, weaving study practices into the social fabric of their wider lives. That was indeed a pleasantly surprising discovery. In the next two sub-sections, we provide details of both part 1 and part 2 as listed in Figure 2 above.

\section{Part 1: Co-configuration in pair/group learning tasks}

\section{Working methods}

As mentioned, a central pedagogical element of the online courses was the buddy system which was designed to facilitate learner interaction and collaboration. The teacher would set collaboration tasks and recommend tools, working methods, divisions of labour, and so on. Students would enact the buddy system, pairing or teaming up mostly in the first few weeks. Buddies would negotiate and co-configure the generic learning tasks to better fit their special interests and needs. Various ways of working together emerged from the interview data. The following are typical working methods reported by the participants. (Note: Pseudonyms are used for all participants.)

Meet up with buddy once a week, every Friday, face-to-face, work on the tasks. Mainly use the virtual room when recording. A group of three people. Same group throughout. (David)

... with my buddy. We often have a ... what I call "a coffee time" first, where we have a conversation about ourselves, and what we were doing, things going in our lives. We were doing this sort of social building, ... yes, all online, ... Part of the plan was to talk about a little then go into the lessons, and build that social cohesion. One of the other things I did in groups was often sharing photos and things that help present the human body when you don't have one online ... I might have shared some photos of the children ... (Peter)

(When) constructing the conversation (for oral presentation) - I would cover, e.g., Lessons $1-3$, and my buddy would cover Lessons $4-6$, then we came together and pieced the conversation together. (Stella)

I always did it (learning the lessons) with someone else. I think you learn language faster when you have someone to practice with. (Even) for the "self-recording tasks", I also did it together with buddies, went through the lessons together, practice together, then record it. (Lynn)

Some students used the course's design for collaborative learning as a springboard for co-configuring major learning tasks. The following is a particularly striking example, previously invisible to the teacher-designer.

I had an idea that ... OK, since we are learning the money, learning about buying food, vegetables and stuff, I said "Why don't we make a scene that we are all actors in the scene, two of us going to the market, and two of us were the sellers?" So I wrote up the script in English, and then just translated it into Mandarin. So I wrote the whole script and then I got the guy to come in and help me. Cos I started to translate it into Mandarin, and the one that was stronger, John, he was quite strong in Mandarin ... so he would help to translate some of the words better, and make the phrases sound better, and then he added more stuff in to make it more cohesive. It was good. It was like a big collaboration, where I started it off with the ideas, I said I got these ideas, "Should we do this?" And they said, "Yes, that is 
great", because it actually used everything we were learning. We were putting it in in each area ... Something would come up, like, "What do we do now?", I said, "We could do this part, we can talk about this", and then we would look back, and go ... "Well, we're learning these words here, we should really add them somewhere, we should add them to our script, we would find another scene, or another ... that would incorporate those new words we were learning." (Max)

When students' co-configuration activity can be this extensive, it is clear that ignoring the processes, the contexts, and the mechanisms that mediate between course designs and educational outcomes is very risky.

\section{Working relationships}

Participants stated that one of the most challenging things in fully online language learning is the lack of interaction and practice with peers. This corresponds with literature findings on the major difficulties online learners encounter: (a) getting hold of classmates and finding suitable time to work together and (b) forming a pair or teaming up and working collaboratively (Comas-Quinn, de los Arcos, \& Mardomingo, 2012; Grooms, 2003; Muilenburg \& Berge, 2005; Murphy \& Stewart, 2017; Wallace, 2003).

Aware of this potential problem, most participants developed strategies and reported distinctive ways of co-configuring working relationships. For example, Michelle voiced a concern that arises from the intangibility of online courses. In the absence of the structuring resources provided by a campus-based course, she articulated a need for the support and encouragement of another person, to buttress her selfmotivation.

Because I feel like, if you are taking an online [course], it feels like it doesn't exist. That's not a [course] you are taking. So you forget to do the work, and you just don't bother, because you don't have that physical aspect where you look at the time and you have to walk into a class for the lecture, that kind of things. I am not an online paper kind of person ... for the Chinese one, it was very good, because I had my partner as a kind of support person. She would text me and say that we had to get that done, blah blah blah. Then you would feel kind of bad ... well not bad ... but I have to get the work done, not let her down. That would encourage me to do the work, remember to read the course materials ... (Michelle)

Roles and divisions of labour

Some students were rather reluctant to take the lead role in collaborative work. When asked whether she had taken charge in group collaboration, Elizabeth said:

No. Actually, I would let them do what they wanted. I sort of left them ... somehow, I think that's best for us ... (taking a) "passive leadership" ... I would drop in little suggestions: so what about we do this, what about we do that'? (Elizabeth)

On the other hand, some participants acknowledged that they had taken the lead role.

Yes, I did take a lead role. I am naturally the one who does take the lead ... because it is... um ... a comfortable position for me. I was always able to lead easily. (Max)

One student was grateful that his buddy took leadership and sometimes guided him through material he had missed:

There were times I relied on his leadership, particularly when I missed the lesson and had been away. I think I missed a few lessons, 3 or 4 out of the 12. And he would tie me in what I missed in the lesson ... So some weeks he would walk me through the class, what we had covered in the class. If I didn't have that, I would have completely ... he would talk about something that happened in the class, that weren't in any of the resources. That was very helpful. (Peter)

Participants were asked about how they divided up the group tasks. Most participants reported that they had established and maintained a cooperative, happy environment and the division of work had been pretty equal and fair. Some participants said that they sometimes contributed more, but they did not mind. One 
participant (Kim) said her buddy always seemed to do the work on the spot, while she herself had come prepared in advance, but she was "OK with that" because her buddy "was busy with work in other courses". Another participant reported:

(division of labour) ... pretty fair, don't remember feeling that I have done any more than anybody else. I can remember actually in some other [courses] where we had to do collaborative things, particularly in the cultural [course], well, I did feel I had to do in fact quite a bit more... I was quite happy about this online course. (Eddie)

\section{Learning spaces}

Online learning is often described as learning that can be done anywhere. However, as Gourlay and Oliver (2017) note, places for study are "made, not just found" (p. 81); students create congenial learning places by "bringing together specific combinations of space and technology" (p. 80). They use technology to create "moorings" (p. 76) that help connect places and render them suitable for learning, resulting in a greater variety of places than would otherwise be the case.

Participants in this study did likewise. The teacher, using the virtual classroom within the university's VLE, had set up a pair/group meeting room. The teacher had considered the virtual room adequate for students to do the pair/group tasks required. Many participants reported, however, that they did not find the institution's setup convenient or good enough for their particular purposes. Instead, the majority of them looked at how group work was meant to be conducted in the virtual room, and then configured other spaces for their own pair/group meetings. They explored other possible online places, and these were places they liked to use: Skype, Facebook, Messenger, WeChat, and Google Docs (for writing the presentation scripts together). The favourite place was Facebook, because, they said, communicating there was "easier and quicker".

I did use the virtual classroom, but also use Skype. And I had a group in the city campus, meet weekly. (Courtney)

Another approach was to configure a material place for meeting face-to-face, for example, making a booking for a co-lab (group collaboration room - where some noise is allowed) at the library. Gallagher et al. (2017) have drawn attention to the need for designers of online or distance education programs to take into account how students create learning places in which they have an adequate level of control over sound. This is particularly relevant for students, like those in our study, who needed to practise speaking and listening. Gallagher et al. (2017, p. 97) note that designers for distance education need:

... a greater understanding of modal coherence, or how sound, images and texts work together. Furthermore, there is a pragmatic need for distance educators to understand how territoriality (Fluegge 2011), or the active carving out of space for study purposes, is enacted across the aural and material planes, and how this in turn influences students' engagement with their program and institution.

To this, we would now add that students can also benefit from having greater awareness of these constraints and affordances, as well as strategies for carving out congenial learning places for collaborative work.

Katie's quote (below) gives a very nice example of carving out a quiet space, where home space avoids the distracting effects of other people:

With this specific class, (my study) was at home, in my room, which was a good thing. What I enjoyed about the online studies was ... compare it with you go to a lecture, you get distracted by the people around you. Whereas online study was "me" and my computer, and listening to the sounds, with my coffee cup. I wasn't distracted by people walking around, people moving chairs, or people going to the bathroom ... Yes, it is a big thing, depends on if you get distracted often or not. (Katie)

Tools

Students reported a range of ways they co-configured the tools they needed for working with others: from sticking to the tools recommended by the teacher to using a mixture of the university tools and other tools 
which students found elsewhere. Only a handful of participants reported that it was sufficient using just the teacher's tools. For example, regarding the regular recording and submission of individual and pair or group oral presentations, one participant said:

I didn't use the University's online setup to record the oral work, because I wasn't familiar/confident enough to use it. Later, my buddy told me how to use it, I became more comfortable with it, and I started to use it. (Debbie)

However, many participants told us things such as the following:

I did not find the university's platform was good enough, because there was a lot of downloading, it took a lot of time - wasted so much time. (Stella)

I could not work out the way to use the recording setup, my partner and I Googled and found and downloaded a recording program - Garage Band - to record and send files to the teacher. (Michelle)

It seems that students would use what the university had provided as a way of making sense of what was expected of them. They were then better placed to choose other things, for example, co-configuring new tools, new spaces, and working methods, which functioned better for them and their buddies. In this way, successful design does not depend on the take-up of recommended tools or spaces; it can succeed through communicating what is needed (Krippendorff, 2006).

\section{Part 2: Co-configuration of wider social environment for learning}

When learning a new language, learners' lives change significantly (van Lier, 2007). Second language (L2) learners interact within and beyond the classroom. Scholars in the field of identity, motivation, and L2 learning point out that attaining L2 competency inevitably involves the issue of social identity and the development of a L2 self (Dörnyei \& Ushioda, 2009; Gardner, 2010; Goharimehr, 2017; Norton, 2013; Ushioda, 2011). L2 learners visualise themselves as proficient users of the target language in the future and construct new ways of linking themselves to the new worlds in order to forge new identities. They desire to mingle with the native speakers, are motivated to be closer to the L2 community members, and strive to become not only competent in L2 but also the ideal L2 self.

Participants' experiences in this study mirrored what is said above. What comes across very strongly, in the data we collected, is that the majority of participants were keen on making use of the resources in their own wider social environment and building a helpful and supportive social structure to enhance their learning. The various ways students involved other people in their learning showed agency and creativity. They extended their social learning environment in ways that involved Chinese-speaking and non-Chinesespeaking friends, acquaintances and relatives, as well as face-to-face and online interactions.

Some students mentioned that they had Chinese-speaking friends or relatives and described how they involved these people in their language learning activities.

My wife, a Chinese, helped me with the role-play. She would ask the questions (which we were supposed to learn), I answered. (Max)

(With a new lesson, I would) go over, if didn't understand, asked my Chinese friend. They gave me an explanation, especially (teaching me) the tones and sounds. (Michelle)

I used my newly learned language at work, and practiced on my boyfriend's mum (who is a Chinese native speaker). (Lucy)

Ahead of the exam, my colleague Susan, I did some practice with her. She was very helpful, helping me with my pronunciation ... Ahead of the exam ... she would pop things out and do pop quiz with me, which was quite helpful. She would just randomly choose something and put (pull?) up a character and say "what is this one?" I said: Oh, oh, my God. She would say: "You are too slow, Peter, Fail!" (Peter) 
Some students reported involving friends and relatives in their language learning activities, even though they were not Chinese speaking.

I would get my wife to ask the questions, I then answered. ... No, she doesn't know any Chinese. I just transcribed the sounds and she read them out. (David)

I asked my husband to say the questions randomly. He doesn't know any Chinese, I gave him the sounds, and told him the tones, but when I heard him, I was more confused .... hahaha. ... that still teach my hearing (listening). Also with the vocabulary, he would say a word, I would guess what it meant ... (Debbie)

Students also described how they sought out Chinese-speaking people from the wider community to help them with their language learning.

Most important, having native speakers to help, find language partners (is a good way to study). I found a couple of language partners, they would help me. I helped them with English. I got them to correct my Chinese. (Stella)

I would practice on the checkout person at PaknSave [supermarket] when I went shopping. I would make a point of going to her checkout line. (Eddie)

I would practice my Chinese on Chinese customers in our family business. One time I managed to get the message across to a customer. My husband (who did not expect that I could use my newly learned Chinese to do so) was impressed. (Daisy)

I went to a church, where there were a lot of Chinese people. Some of them were very good friends with me. And they were all native speakers. I spoke quite a bit of Chinese with them as well. (David)

Some students also reported making use of online or social media resources to broaden their learning experience. They also sought face-to-face L2 interactions to complement their online learning. They told us, often enthusiastically, stories of how they integrated both online and face-to-face resources into their wider language practices. For example:

We were a group of five. We went to the website to find Chinese beginner courses as extra resources to learn. (Catherine)

That was my first time doing Chinese and doing it online. I took extra lessons. Enrolled in an 8-week Chinese course, alongside this online course... I was uncomfortable with online learning. I think I needed that re-assurance of face-to-face learning. (Michelle)

I used a social media platform for language practice. It is called Periscope. It is live streaming, there is a map, you click on a Chinese-speaking place and see who is live streaming as well. I would say a sentence, and ask the person "Can you say it in English" and see if I said it correctly. They would correct me. When I was writing the presentation script for recording, I would also get them to check it for me. I am quite thorough; I would send the script to my language partner to check as well. (Stella)

Perhaps the ultimate example in our data set of co-configuring opportunities for learning Chinese came from one student who said:

I went to China in between the course, Shenzhen, practiced with tour guides there. (David)

\section{Conclusions}

In this paper, we have presented the idea of online students co-configuring their study situations. Drawing data from interviews with students who had completed online courses in Chinese, we captured and 
interpreted the ways they made adjustments to what their teachers had designed for them. Our focus was on how students co-configured ways of working with others and pro-actively connected their learning practices to the broader social fabric of their lives. From this research, it seems clear fully online language learning is intensively socially situated and students are actively taking charge of the co-configuration of their social environments, structures, and relationships to try to improve their learning.

Although the findings of this research render a deeper understanding of social co-configuration in fully online language learning, several general and practical implications for the design of online courses can be drawn from this study. Firstly, in online courses, even where students appear to have rejected the tools and resources recommended by the teachers, they may examine what has been designed for them as a way of ensuring that they understand what is intended and required. This gives them a firmer basis for their own co-configurational work. This shows that design can function well as a form of communication, even when the designed products themselves are partially or wholly rejected by the students. Nevertheless, the efficacy of particular designs is still very important, and ongoing reflection and research by designers and teachers are required to minimise student rejection. Secondly, this study shows that many student learning activities are invisible to the teachers. Knowing more about how students co-configure their learning situations is crucially important. In the absence of such knowledge, we are left on the outside of a black box, guessing what may be happening on the inside. One way of making these important mediating processes more visible would be, as suggested (Matthews, Dwyer, Hine, \& Turner, 2018), enrolling students as partners in our educational design and inviting them to talk explicitly about their co-configuration activity.

There are limitations to this study. Firstly, it draws on a small sample of language learners involved in an unusual kind of course - designed as fully online, but, as the data show, co-configured by students in ways that connect activities back to the material world. Secondly, reliance on interviews rather than direct observation means that we depend on students to be able to give a reliable account of how they do what they do. Thirdly, if we had anticipated the extent and sophistication of students' social co-configurational work, we could have added more probing follow-up questions to the interview schedule.

Each of these limitations suggests lines of further research. While the idea of student co-configuration is intuitively plausible, more and broader-based studies are needed to map its extent and character, which is likely to vary across disciplines and teaching methods. Research using semi-structured interviews should be complemented by other forms of data-gathering, including observation (where acceptable) and debriefing interview or focus-group sessions. Taking the idea of students as partners more seriously, research might also explore ways of including opportunities for students to discuss their co-configuration activity in regular course evaluation and feedback processes. The ability to improve one's learning environment is, after all, an important skill for lifelong learners.

\section{Acknowledgements}

Peter Goodyear's participation in this work was supported by a grant from the Australian Research Council: ARC Discovery Project Grant DP150104163 “Modeling complex learning spaces”.

\section{References}

Baydas, O., Kucuk, S., Yilmaz, R. M., Aydemir, M., \& Goktas, Y. (2015). Educational technology research trends from 2002 to 2014. Scientometrics, 105(1), 709-725. https://doi.org/10.1007/s11192015-1693-4

Biggs, J., \& Tang, C. (2007). Teaching for quality learning at university: What the student does (3rd ed.). Buckingham, England: Open University Press.

Bligh, B., \& Crook, C. (2017). Learning spaces. In E. Duval, M. Sharples, \& R. Sutherland (Eds.), Technology enhanced learning: Research themes (pp. 69-88). Cham, Switzerland: Springer. https://doi.org/10.1007/978-3-319-02600-8_7

Carvalho, L., Goodyear, P. (2014). The architecture of productive learning networks. New York, NY: Routledge. https://doi.org/10.4324/9780203591093

Carvalho, L., Goodyear, P., \& de Laat, M. (2017). Place, space and networked learning. In L. Carvalho, P. Goodyear, \& M. de Laat (Eds.), Place-based spaces for networked learning (pp. 1-10). New York, NY: Routledge. 
Comas-Quinn, A., de los Arcos, B., \& Mardomingo, R. (2012). Virtual learning environments (VLEs) for distance language learning: Shifting tutor roles in a contested space for interaction. Computer Assisted Language Learning, 25(2), 129-143. https://doi.org/10.1080/09588221.2011.636055

Corbin. J., \& Strauss, A. (1990). Grounded theory research procedures, canons, and evaluative criteria. Qualitative Sociology, 13(1), 3-21. https://doi.org/10.1007/BF00988593

Creswell, J. W. (2018). Research design: Qualitative, quantitative, and mixed methods approaches (5th ed.). Los Angeles, CA: Sage.

Crook, C., \& Barrowcliff, D. (2001). Ubiquitous computing on campus: patterns of engagement by university students. International Journal of Human-Computer Interaction, 13(2), 245-258. https://doi.org/10.1207/S15327590IJHC1302 9

DiSalvo, B., Yip, J., Bonsignore, E., \& DiSalvo, C. (2017). Participatory design for learning: Perspectives from practice and research. New York, NY: Routledge. https://doi.org/10.4324/9781315630830

Dohn, N. (2018). Designing for learning in a networked world. Abingdon, England: Routledge. https://doi.org/10.4324/9781351232357

Dörnyei, Z., \& Ushioda, E. (2009). Motivation, language identity and the L2 self. Bristol, England: Multilingual Matters.

Ellis, R., \& Goodyear, P. (2010). Students' experiences of e-learning in higher education: The ecology of sustainable innovation. Abingdon, England: Routledge.

Ellis, R., \& Goodyear, P. (2019). The education ecology of universities: Integrating strategy, learning and the academy. Abingdon, England: Routledge.

Gallagher, M., Lamb, J., \& Bayne, S. (2017). The sonic spaces of online distance learners. In L. Carvalho, P. Goodyear, \& M. de Laat (Eds.), Place-based spaces for networked learning (pp. 87-99). New York, NY: Routledge.

Galley, R., Conole, G., \& Alevizou, P. (2011). Indicators of community table-Presentation transcript. Retrieved from http://www.slideshare.net/OULDI/indicators-of-community-table

Gardner, R. C. (2010). Motivation and second language acquisition: The socio-educational model. New York, NY: Peter Lang Publishing.

Garrison, D. R., Anderson, T., \& Archer, W. (2000). Critical inquiry in a text-based environment: Computer conference in higher education. The Internet and Higher Education, 2(2-3), 87-105. https://doi.org/10.1016/S1096-7516(00)00016-6

Goharimehr, N. (2017). Identity, motivation and english learning in a Japanese context. World Journal of English Language, 7(4), 18-30. https://doi.org/10.5430/wjel.v7n4p18

Gourlay, L., \& Oliver, M. (2017). Students' physical and digital sites of study: making, marking, and breaking boundaries. In L. Carvalho, P. Goodyear, \& M. de Laat (Eds.), Place-based spaces for networked learning (pp. 73-86). New York, NY: Routledge.

Grooms, L. (2003). Computer-mediated communication: A vehicle for learning. International Review of Research in Open and Distance Learning, 4, 1-16. https://doi.org/10.19173/irrodl.v4i2.148

Hauck, M., \& Warnecke, S. (2012). Materials design in CALL: Social presence in online environments. In M. Thomas, H. Reinders, \& M. Warschauer (Eds.), Contemporary computer assisted language learning (pp. 95-115). London, England: Bloomsbury.

Hod, Y., Bielaczyc, K., \& Ben-Zvi, D. (2018). Revisiting learning communities: Innovations in theory and practice. Instructional Science, 46(4), 489-506. https://doi.org/10.1007/s11251-018-9467-Z

Hokanson, B., Clinton, G., \& Tracey, M. W. (Eds.). (2015). The design of learning experience: Creating the future of educational technology. Cham, Switzerland: Springer.

Kabat, K. J. (2014). Time, space, and dialogue in a distance-learning class discussion board. E-Learning and Digital Media, 11(2), 162-175. https://doi.org/10.2304/elea

Kahu, E. R., Stephens, C., Zepke, N., \& Leach, L. (2014). Space and time to engage: mature-aged distance students learn to fit study into their lives. International Journal of Lifelong Education, 33(4), 523-540. https://doi.org/10.1080/02601370.2014.884177

Kirkwood, A. (2000). Learning at home with information and communication technologies. Distance Education, 21(2), 248-259. https://doi.org/10.1080/0158791000210204

Krippendorff, K. (2006). The semantic turn: A new foundation for design. Boca Raton, FL: CRC Press. https://doi.org/10.4324/9780203299951

Laurillard, D., Kennedy, E., Charlton, P., Wild, J., \& Dimakopoulos, D. (2018). Using technology to develop teachers as designers of TEL: Evaluating the learning designer. British Journal of Educational technology, 49(6), 1044-1058. https://doi.org/10.1111/bjet.12697 
Lave, J., \& Wenger, E. (1991). Situated learning: Legitimate peripheral participation. Cambridge, England: Cambridge University Press.

Lefroy, J, Yardley S, Kinston R, Gay S, McBain S, McKinley R. (2017). Qualitative research using realist evaluation to explain preparedness for doctors' memorable 'firsts'. Medical Education, 51(10), 10371048. https://doi.org/10.1111/medu.13370

Markauskaite, L., \& Goodyear, P. (2017). Epistemic fluency and professional education: Innovation, knowledgeable action and actionable knowledge. Dordrecht, The Netherlands: Springer.

Matthews, K., Dwyer, A., Hine, L., \& Turner, J. (2018). Conceptions of students as partners. Higher Education, 76(6), 957-971. https://doi.org/10.1007/s10734-018-0257-y

Muilenburg, L. Y., \& Berge, Z. L. (2005). Student barriers to online learning: A factor analytic study. Distance Education, 26(1), 29-48. https://doi.org/10.1080/01587910500081269

Murphy, C. A., \& Stewart, J. C. (2017). On-campus students taking online courses: Factors associated with unsuccessful course completion. The Internet and Higher Education, 34(Supplement C), 1-9. https://doi.org/10.1016/j.iheduc.2017.03.001

Norton, B. (2013). Identity and language learning: Extending the conversation (2nd ed.). Bristol, England: Multilingual Matters.

O'Brien, B. C., \& Battista, A. (2019). Situated learning theory in health professions education research: A scoping review. Advances in Health Sciences Education, 1-27. https://doi.org/10.1007/s10459-01909900-W

Ouyang, F.; \& Scharber, C. (2017). The influences of an experienced instructor's discussion design and facilitation on an online learning community development: A social network analysis study. The Internet and Higher Education, 35, 34-47. https://doi.org/10.1016/j.iheduc.2017.07.002

Pawson, R., Greenhalgh, T., Gill, H., \& Walshe, K. (2005). Realist review: A new method of systematic review designed for complex policy interventions. Journal of Health Services Research \& Policy, 10, 21-34. https://doi.org/10.1258/1355819054308530

Philip, T. M., Bang, M., \& Jackson, K. (2018). Articulating the "how," the "for what," the "for whom," and the "with whom" in concert: A call to broaden the benchmarks of our scholarship. Cognition and Instruction, 36(2). https://doi.org/10.1080/07370008.2018.1413530

Prosser, M., \& Trigwell, K. (1999). Understanding learning and teaching: The experience in higher education. Buckingham, England: SRHE/Open University Press.

Reimann, P. (2009). Time is precious: Variable-and event-centred approaches to process analysis in CSCL research. International Journal of Computer-Supported Collaborative Learning, 4(3), 239 257. https://doi.org/10.1007/s11412-009-9070-z

Rienties, B., \& Toetenel, L. (2016). The impact of learning design on student behaviour, satisfaction and performance: A cross-institutional comparison across 151 modules. Computers in Human Behavior, 60, 333-341. https://doi.org/10.1016/j.chb.2016.02.074

Saul, J. E., Willis, C. D., Bitz, J., \& Best, A. (2013). A time-responsive tool for informing policy making: rapid realist review. Implementation Science, 8(1), art. 103. https://doi.org/10.1186/1748-5908-8-103

Swan, K. (2001). Virtual interaction: design factors affecting student satisfaction and perceived learning in asynchronous online courses. Distance Education, 22(2), 306-331. https://doi.org/10.1080/0158791010220208

Thomas, M., Reinders, H., \& Warschauer, M. (2012). Contemporary computer-assisted language learning: The role of digital media and incremental change. In M. Thomas, H. Reinders, \& M Warschauer (Eds.), Contemporary computer-assisted language learning (pp. 1-12). London, England: Bloomsbury.

Ushioda, E. (2011). Language learning motivation, self and identity: current theoretical perspectives, Computer Assisted Language Learning, 24(3), 199-210. https://doi.org/10.1080/09588221.2010.538701

van Lier, L. (2007). Action-based teaching, autonomy and identity. Innovation in Language Learning and Teaching, 1(1), 46-65. https://doi.org/10.2167/illt42.0

Wallace, R. (2003). Online learning in higher education: A review of research on interactions among teachers and students. Education, Communication \& Information, 3(2), 241-280. https://doi.org/10.1080/14636310303143

Wong, G., Greenhalgh, T., \& Pawson, R. (2010). Internet-based medical education: a realist review of what works, for whom and in what circumstances. BMC Medical Education, 10, art. 12. https://doi.org/10.1186/1472-6920-10-12 
Wong, G., Greenhalgh, T., Westhorp, G., \& Pawson, R. (2012). Realist methods in medical education research: What are they and what can they contribute? Medical Education, 46(1), 89-96. https://doi.org/10.1111/j.1365-2923.2011.04045.x

Xin, C. (2012). A critique of the community of inquiry framework. International Journal of E-Learning \& Distance Education, 26(1). Retrieved from http://www.ijede.ca/index.php/jde/article/view/755/1333

Corresponding author: Susan Y. H. Sun, susan.sun@aut.ac.nz

Copyright: Articles published in the Australasian Journal of Educational Technology (AJET) are available under Creative Commons Attribution Non-Commercial No Derivatives Licence (CC BY-NC-ND 4.0). Authors retain copyright in their work and grant AJET right of first publication under CC BY-NC-ND 4.0.

Please cite as: Sun, S. Y. H., Goodyear, P. (2020). Social co-configuration in online language learning. Australasian Journal of Educational Technology, 36(2), 13-26. https://doi.org/10.14742/ajet.5102 